\section{Virágzáskésleltetés gyümölcsállományokban}

\section{Szél János}

Debreceni Egyetem Agrár- és Gazdálkodástudományok Centruma, Mezőgazdaság-, Élelmiszertudományi és Környezetgazdálkodási Kar Földhasznosítási, Műszaki és Területfejlesztési Intézet, Debrecen szel.j@agr.unideb.hu

\section{ÖSSZEFOGLALÁS}

Kutatómunkám célja annak kideritése volt, hogy a hütőöntözés miként befolyásolja a virágzáskezdet idöpontját és milyen hatással van a gyümölcsállományok mikroklímájára.

A gyakori (húszpercenkénti) öntözés hatására folyamatosan alacsonyabb hömérsékleten tudtuk tartani a fák, valamint a rügyek hömérsékletét. Ennek eredményeképpen az öntözött fákon a virágzáskezdetek több nappal késöbb következtek be. Bizonyítást nyert, hogy a hütö öntözés hazánk klimatikus viszonyai között alkalmas a virágzáskésleltetésre. Az eljárás eredményeképpen a fagykár elöfordulás valószinüsége jelentösen csökkenthetö, így a termésbiztonság javitható a hazai termötájakon.

Kulcsszavak: mikroklíma módositás, hütőöntözés, virágzáskésleltetés

\section{SUMMARY}

The goal of my research was to find out how cooling sprays affect the onset of flowering and the microclimate int he fruit orchards.

Frequent spraying (every 20 minutes) can keep the temperature of trees and buds lower.As a result the onset of flowering occured several days later in the sprayed trees. It was proven that cooling sprays are suitable for delaying the onset of flowering under the domestic climatic conditions. This procedure can significantly mitigate the risk of frost damage and can improve crop safety.

Keywords: cooling sprays, delaying of flowering, microclimate

\section{BEVEZETES}

Az öntözést a hazai kertészeti gyakorlatban általában vízpótlásra használják. Az esőztető öntözésnek azonban igen erőteljes hatása van a hőmérséklet alakulására. Amennyiben a levegő hőmérséklete magas, azaz eléri vagy meghaladja a $20^{\circ} \mathrm{C}$-ot az esőztető vagy hütö öntözés jelentősen csökkentheti a levegö, illetve a növények felszínhőmérsékletét. A hűtő hatás annál erősebb, minél szárazabb a levegő. A hütő öntözés rendszeres alkalmazásával a gyümölcsállományok hőmérséklete csökkenthető így késleltethetjük a virágzáskezdet alakulását. Korai virágzás kezdet esetén ugyanis nagy az éghajlati fagy előfordulás valószínüsége, ami komoly károkat okozhat a gyümölcsösökben. A hütő öntözés jótékony hatása nemcsak a hőmérsékletcsökkentésben jelentkezik, hanem alkalmas fagyvédelemre is. A fagypont alatti hömérsékletnél a víz és jég egyidejü jelenléte biztosítja, hogy a virágzat illetve terméskezdemény felszínhőmérséklete nulla fok közelében marad, miközben a környező levegő hőmérséklete akár mínusz $8^{\circ} \mathrm{C}$-ra csökken. A hazai és nemzetközi gyakorlatban a fagyvédelmi öntözés elterjedtebb, de hütööntözéses virágzás késletetés alkalmazásával a fagy elleni védekezés hatékonysága jelentősen fokozható. A hütőöntözéses nemzetközi kutatások jelenleg arra irányulnak, hogy meghatározzák a hütőöntözés szerepét a gyümölcsminőségi mutatók alakulásában (Iglesias et al., 2002). A gyümölcsö-sökben alkalmazott állomány feletti mikroszóró-fejekkel hatékonyan javítható a fedőszín (Iglesias et al., 2005), valamint a gyümölcsök antocián tartalmának növelésében is hatékonynak bizonyult (Iglesias et al., 2008).

\section{ANYAG ÉS MÓDSZER}

A kísérleti terület a Debreceni Egyetem AGTC Mezőgazdaság-, Élelmiszertudományi és Környezetgazdálkodási Kar Pallagi kísérleti telepe volt. Az állományi mérések $4 \times 1,5$ m-es térállású, tölcsér koronaformájú Haganta szilva ültetvényben történtek. A Haganta szilva telepítése 2005 tavaszán történt.

A virágzásdinamika alakulását, annak időjárási változóktól való kapcsolatát vizsgáltuk már korábban alma és meggy ültevényekben (Lakatos et al., 2006, 2008, 2009). Most arra vállalkoztunk, hogy megvizsgáljuk azt, hogy miként befolyásolhatjuk a mikroklíma paraméterek alakulását az állományi térben mikroöntözés segítségével. A korábbi eredmények biztatóak voltak (Lakatos et al., 2010). Sikerült igazolni, hogy a hütőöntözés alkalmas módszer az állományi tér fizikai paramétereinek módosításra. Söt, azt is sikerült kimutatni, egyéb gyümölcsfajok esetében is alkalmas a módszer virágzás késleltetésre (Lakatos et al., 2011a), a gyümölcsfajok fiziológia folyamatainak hatékony módosításra (Lakatos et al., 2011b).

A mérésekhez speciális mikroklíma állomást használtunk. A nagyérzékenységű platina hőmérsékletmérő szenzorokat az ágakra, közvetlenül a virágrügyek alá helyeztük. Öt pontban mértünk koronahőmérsékletet, a négy égtáji irányban, illetve a korona geometriai középpontjában. A mintavételezési idő 10 perc volt.

A virágzásdinamika felvételezések Nyéki (1980, 1989, 1990, 2002) vizsgálatai és útmutatásai szerint történtek.

A kísérleti körülmények beállítása 2010 márciusában kezdődött. Kialakításra került egy olyan öntözőrendszer, mely alkalmas a gyümölcsök fagyvédelmének ellátására és jól használható a mikroklíma paramétereinek befolyásolására. A mikro szórófejek rendeltetése a növényi részek nem a víz a párolgás általi hủtésének, illetve a levegő nedvességtartalmának növelése. Jelen esetben célunk a párolgás általi hütés mértékének, tartalmának vizsgálata volt. A virágzáskezdet előtt megköze-lítőleg egy hónappal korábban indítottuk a virágzáskésleltetéses kísérletet. Az állományi térben három szintben helyeztünk el mikro szórófejeket 
(törzstérben, közvetlenül a talaj szintje felett néhány centiméterre, a koronatérben, illetve a koronatér fölött körülbelül fél méter magasságban).

Az öntözési programot úgy állítottuk be, hogy húsz percenként két percig történt az öntözés. A mikro szórófejek egyenletes hütést biztosítottak a teljes fa felületén. Jelen vizsgálatban nem választottuk szét az egyes öntözési szintek hatását mivel ebben az időszakban a párolgás még nem olyan intenzív, hogy a törzstérbe kijuttatott vízgőz mennyiség jelentősen befolyásolná a koronatér hőmérsékletét. Így gyakorlatilag a kontaktpárolgás mutatkozott a leghatékonyabb felszínhőmérséklet csökkentő tényezőnek. Ezért a három magassági szintben elhelyezett szórófej együttes hatását vettük figyelembe.

\section{EREDMÉNYEK}

Fajtánként három öntözött és három öntözetlen fa esetében vizsgáltuk a hütőöntözés virágzáskésleltető hatását. Fánként 100-100 virágot számoltunk le és naponta feljegyeztük a virágzási arányok százalékos alakulását. Az alábbiakban bemutatjuk a hütőöntözés hatását a mikroklíma alakulására, illetve ennek hatását a virágzáskezdet és a virágzásdinamika alakulására.

Az 1 hónapos öntözési program során azt tapasztaltuk, hogy a hőmérséklet átlagos napi menete az öntözött fák esetében $1,5-2,0^{\circ} \mathrm{C}$-kal alacsonyabb volt, mint a nem öntözötteké (1. ábra). Az átlagos különbség a déli órákban elérte a 3-4 ${ }^{\circ} \mathrm{C}$-ot. Legkisebb hömérséklet csökkenést a hajnali órákban tapasztaltunk, ekkor az öntözött állományok $0,5-1,0{ }^{\circ} \mathrm{C}$-kal bizonyultak alacsonyabb hőmérsékletünek, mint a nem öntözöttek. Nem találtunk szignifikáns különbséget a vizsgált gyümölcsfajok esetében az öntözött és nem öntözött mikroklímák hőmérsékletének alakulásában. Ebben az időszakban még nem érvényesül a lombozatnak, a koronaformának a mikroklímára gyakorolt hatása.

\section{1. ábra: Az öntözött és öntözetlen szilva állományok átlagos napi hőmérsékletének alakulása (Pallag, 2010. április 2.-április 30.)}

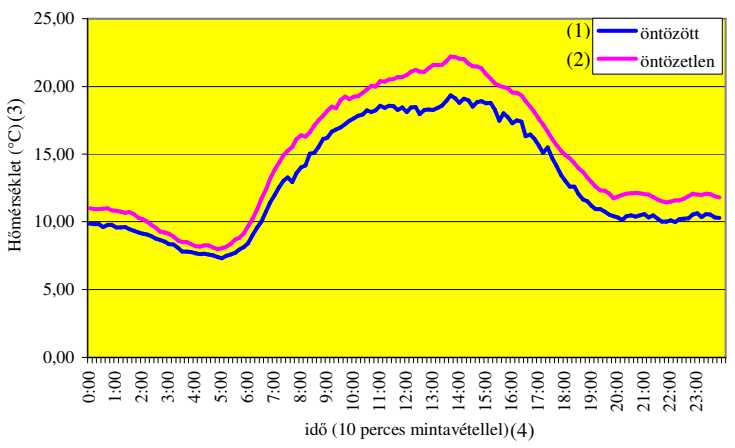

Figure 1: Irrigated and unirrigated daily average temperature in plum orchards in Pallag between 2010. april 2. to april 30. Irrigated(1), Unirrigated(2), Temperature(3), Time(4)

Megvizsgáltuk, hogy a különböző napszakokban történő hűtőöntözés milyen mértékben befolyásolja az állományi terek napi hőmérsékletének alakulását. Igazolni kívántuk, hogy napszaktól függetlenül hatékony lehet a hủtőöntözés az állományi mikroklíma szabályozására. Természetesen a legnagyobb hömérséklet csökkentő hatást azokon a napokon értük el, ahol napi maximum hőmérséklet elérte, illetve meghaladta a $20^{\circ} \mathrm{C}$ ot. A reggeli órákban elkezdett hütő öntözés hatására a déli órákra virágrügyek hömérsékletét $7-8{ }^{\circ} \mathrm{C}$-kal sikerült csökkentenünk az szilva állományokban (2. ábra).
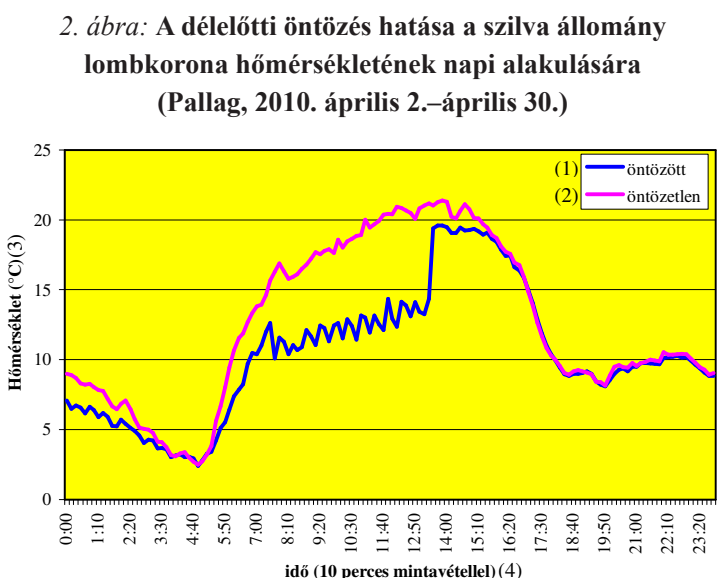

Figure 2: The effect of morning irrigation for shroud temperature in plum orchards in Pallag between 2010. april 2. to april 30. Irrigated(1), Unirrigated(2), Temperature(3), Time(4)

Jóllehet alacsonyabb hőmérséklet mellett a párolgás általi hütés kevésbé intenzív, de ebben az esetben is csökkenthetjük az állományok hőmérsékletét. A mérési eredmények azt mutatták, hogy a magasabb hőmérsékletủ éjszakákon, amikor a minimum hőmérséklet meghaladta a $10^{\circ} \mathrm{C}$-ot, az éjszakai öntözés számottevően, akár $3,0-3,5^{\circ} \mathrm{C}$-kal is csökkentette a cseresznye állományi terének, a rügyeknek és virágoknak a hőmérsékletét (3. ábra).

3. ábra: Éjszakai öntözés hatása a szilva állományokban (Pallag, 2010. április 2.-április 30.)

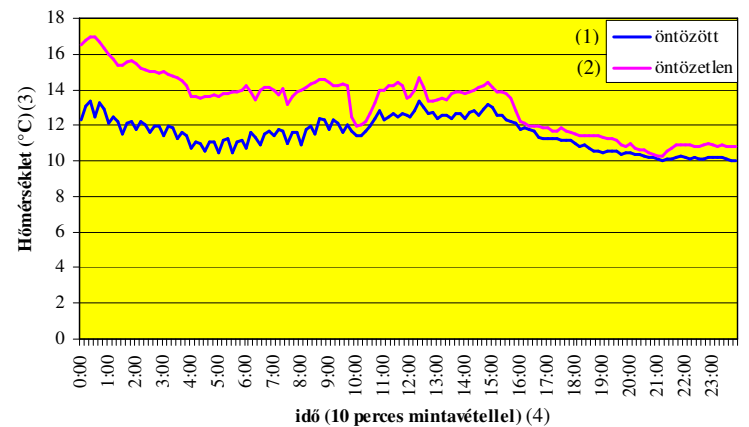

Figure 3: The effect of the night irrigataion in plum orchards between 2010. april 2. to april 30.

Irrigated(1), Unirrigated(2), Temperature(3), Time(4)

Amennyiben a nap folyamán leállítottuk a hütőöntözést 2 óra elteltével a hütőhatás megszünt. Ezért igen fontos a megfelelő gyakorisággal végzett öntözés, mert ritka vízkijuttatás esetén a várt hőmérsékletcsökkentő hatás elmaradhat.

Magasabb hőmérsékletű napokon, amikor a maximum hőmérsékletek elérik a $20^{\circ} \mathrm{C}$-ot, intenzív besugárzásnál a hütő hatás igen gyorsan jelentkezik. Az öntözést 
követően, fél óra alatt, $5^{\circ} \mathrm{C}$-kal csökkenthető a lombkorona hömérséklete. A folyamatos 20 percenkénti víz kijuttatás segítségével az éjszakai órákban is tartható a 3-4 ${ }^{\circ} \mathrm{C}$-kal alacsonyabb hömérséklet az öntözött kultúrák esetében. Az öntözés általi hömérsékletingadozás azonban kisebb az éjszakai órákban.

Az öntözés hatása nemcsak a hőmérséklet csökkenésében jelentkezik, hanem a hőingás mérséklésében is. Azokon a napokon, amikor felhőzet illetve borultság miatt visszaesett a hömérséklet az öntözött állományoknál ez kevésbé volt érzékelhető (4. ábra). Az öntözött állományok esetében magasabb hömérsékletü napokon az intenzív felmelegedés és gyors lehülés egyaránt mérsékelhetö, így a hőstressz kialakulása, napégés kockázat egyaránt mérsékelhető.

4. ábra: A nappali órákban történő öntözés hatása szilva állományokra

(Pallag, 2010. április 2.-április 30.)

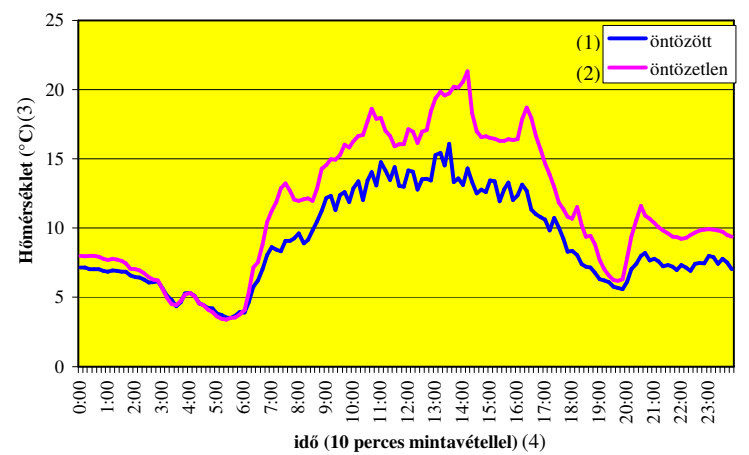

Figure 4: The effect of irrigation in daytime in plum orchards between 2010. april 2. to april 30

Irrigated(1), Unirrigated(2), Temperature(3), Time(4)
A virágzás intenzitásra jellemző volt, hogy a virágzáskezdettől az 50\%-os virágzási arány kialakulásához az öntözött szilva állományban 5 napra, míg öntözetlen állományoknál csupán 4 napra volt szükség. Az öntözetlen szilva virágzása április 6-án kezdődött, míg az öntözött állományoknál 4 nappal később következett be (5. ábra)

Szilva állományoknál azt vehettük észre, hogy az öntözött állomány lassabb virágzási üteme a virágzás végig jellemző maradt. A teljes virágzás öntözetlen körülmények között április 17-én befejeződött, míg az öntözött állományban április 26-án következett. A virágzás időtartama két nappal hosszabbodik meg öntözés hatására.

\section{5. ábra: A virágzásdinamika alakulása öntözött és öntözetlen szilva állományban Pallagon (Pallag, 2010. április 2.-április 30.)}

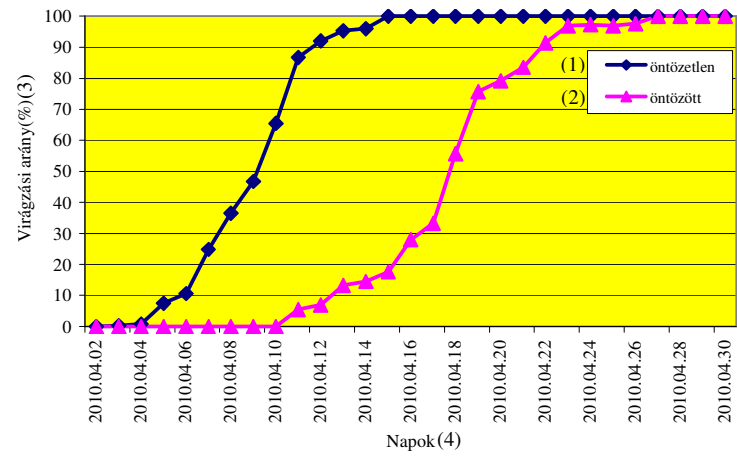

Figure 5: Flowering dynamic in irrigated and unirrigated plum orchards between 2010. april 2. to april 30.

Irrigated(1), Unirrigated(2), Flowering rate(3), Days(4)

\section{IRODALOM}

Iglesias, J.-Salvia, L.-Torguet, L.-Cabús, C. (2002): Orchard cooling with overtree microspinkler irrigation to improve fruit colour and quality of 'Topred Delicious' apples. Sci. Hortic. 93: 39-51.

Iglesias I.-Salvia J.-Torguet, L.-Montserrat, R. (2005): The evaporative cooling effects of overtree microsprinkler irrigation on 'Mondial Gala' apples. Scientia Horticulturae. 103. 3: 267-287.

Iglesias, I.-Echeverría, G.-Soria, Y. (2008): Differences in fruit colour development, anthocyanin content, fruit quality and consumer acceptability of eight 'Gala' apple strains. Scientia Horticulturae. 119. 1: 32-40.

Lakatos, L.-Szabó, T.-Szabó, Z.-Soltész, M.-Nyéki, J. (2009): Relation of sour cherry blooming dynamics and meteorological variables. International Journal of Horticultural Science. 15. 4: $17-23$.

Lakatos, L.-Szabó, T.-Racskó, J.-Soltész, M.-Szabó, Z.-Nagy, J.Nyéki, J (2006): Effects of weather characteristics on blooming dates ina $\mathrm{n}$ aple gene bank plantation between 1984 and 2001. International Journal of Horticultural Science. 12. 2: 37-44.

Lakatos L.-Szabó T.-Soltész M.-Sun, Z.-Wang, Y.-Szabó Z.-Nyéki J. (2008): Időjárási változók hatása a meggy virágzástartamának alakulására. „Klíma-21” Füzetek. 53: 60-67.
Lakatos L.-Nyéki J.-Szabó Z.-Soltész M.-Veres E. (2010): Mikroklíma módosítás lehetőségei gyümölcsültetvényben. Az élhető vidékért 2010 - Környezetgazdálkodási Konferencia. Konferencia kötet. Természeti erőforrásaink a globális környezeti folyamatok tükrében. Siófok. 2010. szeptember 22-24. 282-287.

Lakatos L.-Gonda I.-Soltész M.-Szabó Z.-Sun, Z.-Nyéki J. (2011a): Mikroklíma vizsgálatok őszbarack és szilva állományban. „Klíma-21” Füzetek. 64: 45-53.

Lakatos L.-Soltész M.-Gonda I.-Sun, Z-Szabó Z-Nyéki J. (2011b): Virágzáskésleltetés és mikroklíma módosítás hütőöntözéssel, cseresznye-, őszibarack és szilvaültetvényben. „Klíma-21” Füzetek. 64: 54-61.

Nyéki J. (1980): Gyümölcsfajták virágzásbiológiája és termékenyülése. Mezőgazdasági Kiadó. Budapest. 334.

Nyéki J. (1989): Csonthéjas gyümölcsűek virágzása és termékenyülése. MTA. Budapest. Doktori értekezés (kézirat). $288+110$.

Nyéki J. (1990): A gyümölcstermő növények virágzása, megporzása és termékenyülése. [In: Gyuró F. Gyümölcstermesztés.] Mezőgazdasági Kiadó. Budapest. 61-90.

Nyéki J. (2002): Gyümölcstermő növények virágzása és termékenyülése, ültetvények fajtatársítása. Egyetemi jegyzet. Debrecen. 68. 
